\title{
Assessment of Bacterial Blight Tolerance of Persian Walnut Based on Immature Nut Test
}

\author{
Attila BANDI ${ }^{1,2 *}$, Mária HEVESI ${ }^{1}$, Zsolt SZANI ${ }^{3}$, Magdolna TÓTH ${ }^{1}$ \\ ${ }^{I}$ Corvinus University of Budapest, Faculty of Horticultural Science, Department of Pomology, Villanyistr. 29-43, Budapest, \\ Hungary; attilabandi@uni-convinus.hu;maria.hevesi@uni-corvinus.hu;magdolna.toth@uni-corvinus.bu \\ ${ }^{2}$ Sapientia University, Faculty of Technical and Human Science, Department of Horticulture, Sighișoarastr. 1/C, Tîrgu-Mureș, \\ Romania;bandiattila@msssapientiaro(*orrespondingauthor) \\ ${ }^{3}$ National Food Chain Safety Office, Variety Testing Department for Horticultural Crops, KeletiK. str.24, Budapest, Hungary; SzaniZs@nebih.gov.bu
}

\begin{abstract}
Bacterial blight is one of the most serious diseases affecting Persian walnut (Juglans regia L.). Susceptibility to this disease was evaluated by artificial inoculation in an in vitro experiment for cultivars developed in Hungary and for selections from Transylvania. Thirty pieces of immature fruit of 11 walnut cultivars and 10 selections were inoculated by punction using a suspension containing a mixture of Xaj-isolates of controlled virulence. As control, a moderate resistant $(\mathrm{mR})$ 'Pedro' and a highly susceptible $(\mathrm{hS})$ 'Milotai intenziv' cultivars were used. After ten days the diameter of the necrotic area around the inoculation points was measured and the disease rate (DR) was noted. For the calculation of indexes it was taken the structure of the lesions (diffuse or defined margin) into consideration. None of the 21 cultivars/selections analysed were found to be hardly resistant, although all of them showed a higher degree of resistance than the susceptible control ('Milotai intenzív'). The majority of the analysed cultivars fit into the moderate susceptible $(\mathrm{mS})$ and moderate resistant $(\mathrm{mR})$ group. 'Milotai kései' and SZEN-10, had a notable reaction as considered to be moderate resistant (mR), showed a similar degree of resistance compared to the control cultivar 'Pedro'. It was concluded that these cultivars, based on their resistance to Xanthomonas arboricola pv.juglandis, could be proposed as resistance gene sources, as well as for production purposes in the environmental conditions of the Carpathian Basin.
\end{abstract}

Keywords: artificial inoculation, in vitro, isolates, Juglans regia L, stress, Xanthomonas

\section{Introduction}

Walnut trees may suffer stress from abiotic or biotic environmental factors, which can lead to crop failure. The bacterial blight disease, Xaj (Xanthomonas arboricola pv.juglandis (Pierce)) (Vauterin et al.,1995) is one of the most serious diseases affecting Persian (English) walnut (Juglans regia L.) (Loreti et al., 2001). The disease has been known since the end of the $19^{\text {th }}$ century (Ferraris, 1927) and is widespread in walnut growing areas. It causes severe damage to leaves, twigs, buds, petioles, rachides, male and female catkins, nutlets and kernels, and is considered to be a major cause of reduction in fruit yield and tree vigour (Belisario et al., 1999). The damage produced by this pathogen is predisposed by wet springs. Rainy springs, dew and continual high humidity conditions are favourable to the development of severe blight, resulting in significant crop loss (Belisario, 1997). If this happens just before and after the flowering time, it may cause losses of $50 \%$ to $80 \%$ of the crop (Charlot and Radix, 1993). The bacteria enter the walnut tissues through natural openings, such as stomata and damaged tissues (Sharma and Sharma, 1999). All succulent new growths are reported to be very susceptible to the disease, becoming more resistant when maturing (Belisario et al., 1997).
Susceptible cultivars may have an increased level of damage on new plantings. Soon after the walnut blight was first described (Pierce, 1901), there were many reports of resistance to the disease (Soltani and Aliabadi, 2010). Resistance of trees has been evaluated in orchard condition, so it has not been clarified whether the absence of blight was due to disease escape or to an unknown form of resistance. A different susceptibility to walnut blight within walnut cultivars has been reported. Several authors, Aletà and Ninot (1993), Germain (1997), Woeste et al. (1992) have discovered no resistant cultivars; however 'Franquette' and 'Hartley' were reported as resistant cultivars (Belisario, 1997; Belisario et al., 1999).

Using the in vitro method, assessment of the resistance of walnut genotypes to bacterial blight has been carried out in several studies (Belisario, 1997; Belisario et al., 1999; Martins, 1997; Soltani and Aliabadi, 2010; Özaktan et al., 2007; Tsiantos et al., 2008). Detailed cultivar examination offers the potential of reducing the disadvantageous influence of the main stress factors (Szani, 2009). Searching for the sources of resistance is important, since large walnut trees are not easy to treat, and furthermore, increasingly copper-resistant Xaj strains are developing (Solar et al., 2007). 
254

Table 1. Examined walnut cultivars and selections

\begin{tabular}{|c|c|c|}
\hline Cultivar or selection denomination & Parentage & Origin \\
\hline Hartley & Franquette $\mathrm{x}$ Mayette ${ }^{\mathrm{a}}$ & USA \\
\hline Pedro & Conway Mayette $\mathrm{x}$ Payne ${ }^{\mathrm{a}}$ & USA \\
\hline Milotai 10 & Selection & $\mathrm{HU}$ \\
\hline Alsószentiváni 117 & Selection & $\mathrm{HU}$ \\
\hline Alsószentiváni 118 & Selection & $\mathrm{HU}$ \\
\hline Milotai intenzív & Milotai $10 \times$ Pedro $^{\mathrm{b}}$ & $\mathrm{HU}$ \\
\hline Milotai kései & Milotai $10 \times$ Pedro $^{\mathrm{b}}$ & $\mathrm{HU}$ \\
\hline Milotai bőtermő & Milotai $10 \times$ Pedro $^{\mathrm{b}}$ & $\mathrm{HU}$ \\
\hline Alsószentiváni kései & Alsószentiváni 117 x Pedro ${ }^{\mathrm{b}}$ & $\mathrm{HU}$ \\
\hline Bonifác & Alsószentiváni 117 x Pedro ${ }^{\mathrm{b}}$ & $\mathrm{HU}$ \\
\hline M-10-25 & Milotai $10 \times$ Pedro $^{\mathrm{b}}$ & $\mathrm{HU}$ \\
\hline SZEN-10 & selection & $\mathrm{RO}$ \\
\hline ALB-22 & selection & $\mathrm{RO}$ \\
\hline FFA-11 & selection & $\mathrm{RO}$ \\
\hline OZSD-37 & selection & $\mathrm{RO}$ \\
\hline SAR-33 & selection & RO \\
\hline SOM-50 & selection & $\mathrm{RO}$ \\
\hline SOM-90 & selection & $\mathrm{RO}$ \\
\hline SOM - 101 & selection & $\mathrm{RO}$ \\
\hline SOM-120 & selection & RO \\
\hline SOM-274 & selection & $\mathrm{RO}$ \\
\hline
\end{tabular}

Tulecke and McGranahan, 1994

'Szentiványi, 1990

Table 2. The evaluation of disease severity based on the infection of immature walnut fruits

\begin{tabular}{lc}
\hline Disease appearance/diameter of spots $(\mathrm{mm})$ & Scale of susceptibility \\
\hline No symptoms & 0 \\
\hline Less than $1.00 \mathrm{~mm}$, superficial and diffuse spots on the inoculation point & 1 \\
Slight blackening on the inoculation point of nut by $1.01 \mathrm{~mm}$ to $2.00 \mathrm{~mm}$ & 2 \\
Blackening on the inoculation point of nut by $2.01 \mathrm{~mm}$ to $5.00 \mathrm{~mm}$ of delved spot & 3 \\
Blackening on the inoculation point of nut more than $5.01 \mathrm{~mm}$ of crater- type spot & 4 \\
\hline
\end{tabular}

Based on the results of previous evaluations and open field examinations (Thiesz et al., 2007, 2009; Szani, 2009), there was identified a different degree of susceptibility/resistance in the analysed populations and registered cultivars. However, in most open field assessments, the disease was detected by means of the leaf. The degree of fruit infection has been investigated to a lesser extent. Therefore, it was considered necessary to carry out artificial inoculation in controlled circumstances. The aim of the study was to evaluate the susceptibility to $X a j$ of the cultivars improved in Hungary, and of the selections from Transylvania, by means of an artificial inoculation technique in an in vitro experiment.

\section{Materials and methods}

\section{Plantmaterial}

During the research between 2010 to 2013, it was evaluated the degree of susceptibility of the cultivars listed in Table 1, in comparison to 'Pedro', moderate resistant $(\mathrm{mR})$ and 'Milotai intenziv' highly susceptible (hS), used as control cultivars. The samples were collected before shell hardening in June, from the Trial Station of the National Food Chain Safety Office at Pölöske (HU) and from farmer orchards in Transylvania (RO).

\section{Bacteria}

For the artificial inoculation there were collected 61 isolates from different walnut-growing areas of Hungary and Transylvania. The ability to induce hypersensitive reaction was examined on the tobacco leaf - Nicotiana tabacum L. (Klement, 1963) - and bean pod (Phaseolus vulgaris L.). The pathogenicity

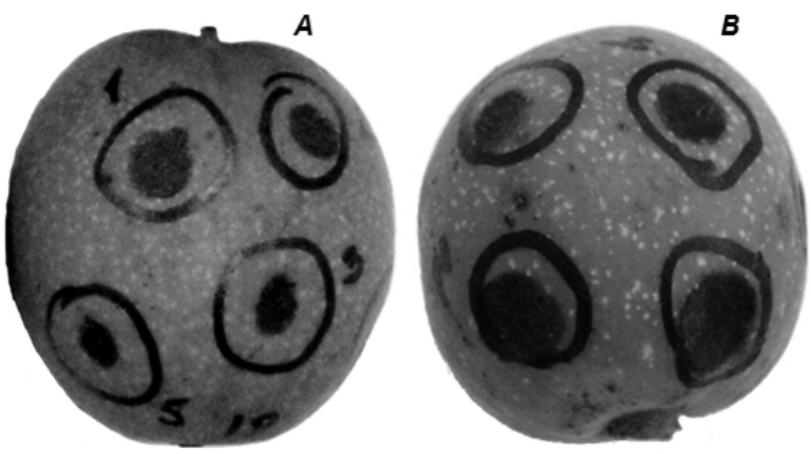

Fig. 1. The results of pathogenicity test on immature walnut fruit (A: SOM-120; B: ALB-22)

test was controlled on immature walnut fruits (Fig. 1). For the artificial inoculation, it was used a mixture of isolates from a homogeneous bacteria population (based on the phenotype) from the green husk of two walnut fruits, one originating from Hungary B02489 (HU), and the other from Transylvania B02490 (RO). They showed the same degree of virulence. The biochemical identification of the two isolates (henceforth, 'strain') was already carried out in previous studies (Bandi et al., 2014).

\section{Inoculation}

For the artificial inoculation it was adjusted a suspension of

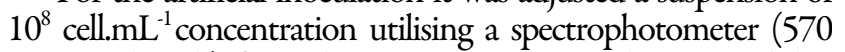
$\mathrm{nm}$ wavelength) from the respective strains. The susceptibility 


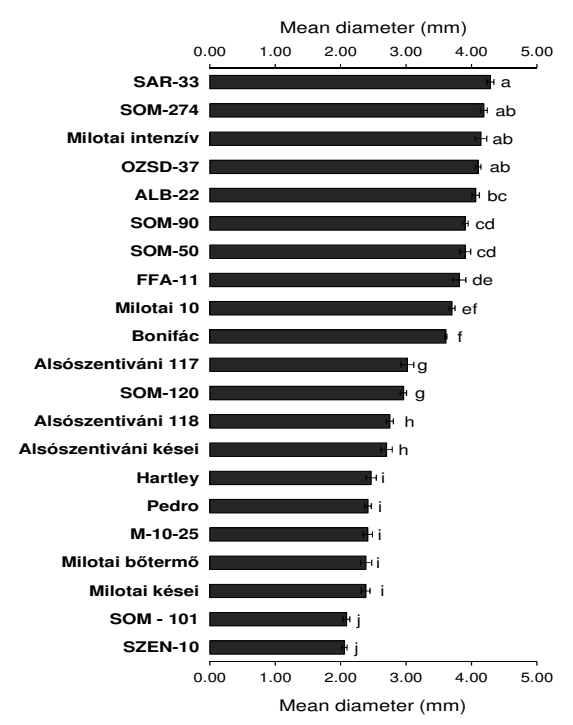

Fig. 2. Mean diameter of spots produced by two Xaj isolates around the inoculation (2010-2013)

Values with the different letter indicate cultivars that differ significantly (Duncan's test, $\mathrm{p} \leq 0.05$ ); The error bars show $\mathrm{SE}$ of the mean

tests were conducted based on the method of Özaktan et al. (2008).

During the investigation, 30 crops (20 for artificial inoculation and 10 for control treatment) were collected. Each of the 20 fruit was injected in five $\left(0.5 \mathrm{~cm}^{2}\right)$ places with a $20 \mu \mathrm{l}$ bacterial suspension. The susceptibility of each cultivar was evaluated for 100 instances of infection. The control fruits were inoculated with sterile distilled water. The inoculated fruits were then placed in closed transparent plastic boxes in order to assure an adequate humidity $(85 \%)$ and temperature $\left(26-28^{\circ} \mathrm{C}\right)$.

\section{Assessment of the susceptibility offruits}

After inoculation, the fruits were monitored continuously, and on the tenth day the symptoms were summarised. In order to determine the mean diameter of the necrotic area, a digital slide-calliper attached to a computer (providing accuracy to the millimetre) was used. To determine the degree of the susceptibility, there were taken into consideration all the developed symptoms, as well as those that did not appear. After this, the dimensions of the necrotic areas were evaluated based on the five-stage scale developed by Özaktan et al. (2008) (Table 2).

\section{Determination of cultivar susceptibility}

Using data from the infection scale and the formulas found in the related literature, different indexes were produced. The disease rating (as an index showing the incidence of the disease) was determined by using data from the infection scale and the following formula by Bertrand and Gottwald (1986):

\section{Disease rate $=\sum\left(a_{i} x f_{i}\right) / n$}

where $a_{i}$ - scale value (index of infection), $f_{i}$ frequency referring to the disease rate; $n$ - the number of analysed fruit per cultivar.

\section{Statistical evaluation}

The data were evaluated using the SPSS software (IBM SPSS 22.0, Chicago, IL). The statistical analyses were determined

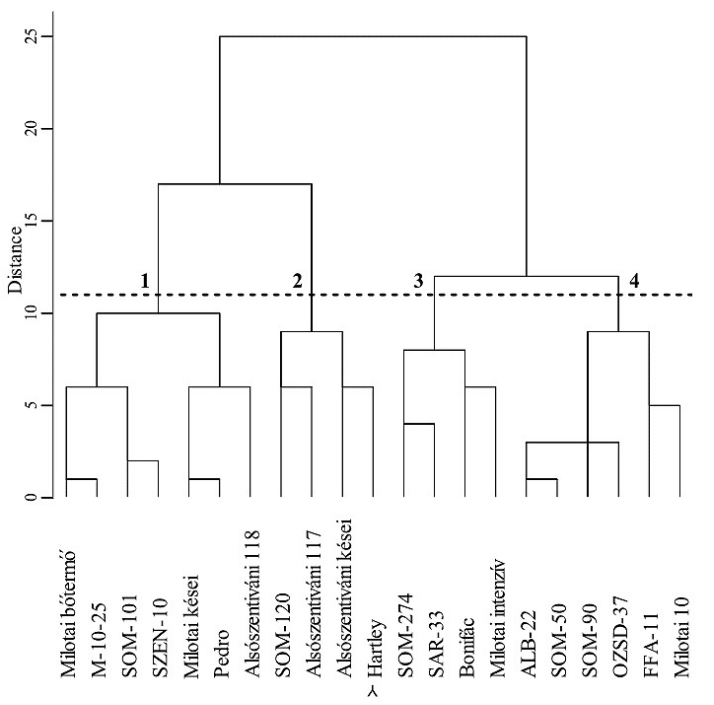

Fig. 3. Dendogram based on the average linkage (between groups) method of cluster analysis by means of necrotic spot diameter and disease rate of the walnut blight infection for walnut cultivars (20102013)

Numbers on the dendogram indicate different groups: 1: moderate resistant $(\mathrm{mR}), 2$ : moderate susceptible $(\mathrm{mS}), 3$ : susceptible (S), 4: highly susceptible (hS)

based on the sample size, distribution analysis (KolmogorovSmirnov test) and equivalence of deviation (Levene test). Where the condition of normality was fulfilled, and means proved to be homogeneous, Tukey's multiple range test was used. If homogeneity of distribution was not fulfilled, differences were analysed using the Games-Howell test. In case of an abnormal distribution, the Kruskal-Wallis non-parametric method was applied; then, for the comparison of the pairs, the MannWhitney test was used.

It was accepted the $\mathrm{p} \leq 95 \%$ confidence level. The results were given as average \pm standard error (SE). It was conducted a hierarchical cluster analysis based on four-year data regarding the diameter and disease rate, in order to classify the cultivars into susceptibility groups. The results were represented on a dendogram.

\section{Results and discussions}

The susceptibility of the analysed cultivars was evaluated in different groups according to the experimental year. Table 3 contains annual mean values regarding the disease rate. In the case of several cultivars, major differences between the annual results were noted. Therefore, further research will be required to clarify the susceptibility of 'Alsószentiváni 118' and 'Milotai kései'.

Based on the results of the artificial inoculation from 2010, compared to other cultivars, the mean disease rate value of SZEN-10 was significantly lower $(\mathrm{p}<0.05)$, which means it can be designated to the moderate susceptible class. OZSD37, SOM-90, ALB-22 and SOM-50 cultivars proved to be highly susceptible. In the case of data from 2011, the MannWhitney test classified the cultivars with the average disease rate value under 2 into the homogeneous group (moderate susceptible), being significantly different $(\mathrm{p} \leq 0.05)$. Considering the 2012 disease rate results, the susceptibility of cultivars showed a better differentiation. Based on the statistical evaluation of data, SOM-101 and SZEN-10 proved 
256

Table 3. Disease rate of the analysed walnut cultivars in the individual years ${ }^{2}$

\begin{tabular}{|c|c|c|c|c|}
\hline \multirow{2}{*}{ Cultivar or selection } & \multicolumn{4}{|c|}{ Disease rate $(0-4)$} \\
\hline & $2010^{b}$ & $2011^{\mathrm{c}}$ & $2012^{\mathrm{b}}$ & $2013^{c}$ \\
\hline Hartley & & $2.91 \pm 0.03^{a-c}$ & $2.19 \pm 0.04^{\mathrm{g}}$ & \\
\hline Pedro & & $1.64 \pm 0.21^{\mathrm{gh}}$ & $2.10 \pm 0.03^{\mathrm{gh}}$ & \\
\hline Milotai 10 & & $2.48 \pm 0.24^{\mathrm{de}}$ & $2.90 \pm 0.05^{\mathrm{a}-\mathrm{d}}$ & \\
\hline Alsószentiváni 117 & & $2.39 \pm 0.16^{\mathrm{d}-\mathrm{f}}$ & $2.64 \pm 0.05^{\mathrm{de}}$ & $2.88 \pm 0.10^{\mathrm{d}}$ \\
\hline Alsószentiváni 118 & & $1.52 \pm 0.38^{\mathrm{gh}}$ & $2.53 \pm 0.02^{\mathrm{ef}}$ & \\
\hline Milotai intenzív & $2.55 \pm 0.20^{a-c}$ & $2.57 \pm 0.24^{\mathrm{b}-\mathrm{e}}$ & $2.80 \pm 0.08^{\mathrm{b}-\mathrm{e}}$ & \\
\hline Milotai bőtermő & & $2.31 \pm 0.06^{\mathrm{ef}}$ & $2.18 \pm 0.08^{\mathrm{g}}$ & \\
\hline Milotai kései & & $1.29 \pm 0.29^{\mathrm{h}}$ & $2.16 \pm 0.01^{\mathrm{g}}$ & \\
\hline M-10-25 & & $1.91 \pm 0.04^{\mathrm{gh}}$ & $2.21 \pm 0.01^{\mathrm{fg}}$ & \\
\hline Alsószentiváni kései & & $2.72 \pm 0.03^{\text {a-e }}$ & $2.21 \pm 0.05^{\mathrm{fg}}$ & \\
\hline Bonifác & $2.13 \pm 0.40^{\mathrm{bc}}$ & $2.50 \pm 0.08^{c-e}$ & $2.95 \pm 0.01^{\mathrm{a}-\mathrm{d}}$ & \\
\hline ALB-22 & $3.09 \pm 0.08^{\mathrm{a}}$ & $3.09 \pm 0.03^{\mathrm{a}}$ & $2.96 \pm 0.02^{\mathrm{a}-\mathrm{d}}$ & $3.06 \pm 0.00^{\mathrm{a}}$ \\
\hline FFA-11 & $2.58 \pm 0.12^{a-c}$ & $2.95 \pm 0.03^{a-c}$ & $2.93 \pm 0.03^{\mathrm{a}-\mathrm{d}}$ & $3.00 \pm 0.00^{\mathrm{bc}}$ \\
\hline OZSD-37 & $3.01 \pm 0.01^{\mathrm{a}}$ & $3.08 \pm 0.01^{\mathrm{a}}$ & $2.98 \pm 0.03^{a-c}$ & $3.01 \pm 0.01^{\mathrm{b}}$ \\
\hline SAR-33 & $2.73 \pm 0.23^{\mathrm{ab}}$ & $2.73 \pm 0.23^{a-c}$ & $3.06 \pm 0.07^{\mathrm{ab}}$ & $3.10 \pm 0.05^{\mathrm{a}}$ \\
\hline SZEN-10 & $1.85 \pm 0.10^{c}$ & $2.24 \pm 0.09^{\mathrm{fg}}$ & $1.89 \pm 0.13^{\mathrm{gh}}$ & $2.48 \pm 0.21^{\mathrm{e}}$ \\
\hline SOM-50 & $3.15 \pm 0.06^{\mathrm{a}}$ & $2.91 \pm 0.08^{a-c}$ & $3.10 \pm 0.06^{\mathrm{ab}}$ & $2.99 \pm 0.01^{c}$ \\
\hline SOM-90 & $3.08 \pm 0.01^{\mathrm{a}}$ & $3.00 \pm 0.02^{\mathrm{ab}}$ & $3.20 \pm 0.06^{\mathrm{a}}$ & $3.00 \pm 0.00^{\mathrm{bc}}$ \\
\hline SOM - 101 & $2.37 \pm 0.05^{a-c}$ & $1.61 \pm 0.09^{\mathrm{gh}}$ & $1.81 \pm 0.09^{\mathrm{h}}$ & $2.30 \pm 0.03^{\mathrm{f}}$ \\
\hline SOM-120 & $2.41 \pm 0.12^{\mathrm{a}-\mathrm{c}}$ & $2.79 \pm 0.06^{\mathrm{a}-\mathrm{d}}$ & $2.69 \pm 0.06^{c-e}$ & $2.88 \pm 0.03^{\mathrm{d}}$ \\
\hline SOM-274 & $2.36 \pm 0.09^{a-c}$ & $3.00 \pm 0.12^{\mathrm{ab}}$ & $2.95 \pm 0.11^{\mathrm{a}-\mathrm{d}}$ & $3.00 \pm 0.00^{\mathrm{bc}}$ \\
\hline
\end{tabular}

${ }^{a}$ The mean values \pm SE of the

'The different letters indicate the significant difference between the cultivars ( $\mathrm{p} \leq 0.05$; Tukey's multiple range test)

'The different letters indicate the significant difference between the cultivars ( $\mathrm{p} \leq 0.05$; Mann-Whitney test)

to be moderate resistant $(\mathrm{mR})$, while moderate susceptibility (mS) was detected for 'Pedro', 'Milotai kései', 'Milotai bőtermö', 'Hartley', M-10-25 and 'Alsószentiváni kései' cultivars. Based on the average data from 2013, similar to the results of previous years, it was determined a significantly low susceptibility in the case of SOM-101 and SZEN-10.

Fig. 2 contains the mean data for the diameter of the necrotic spots. 'Milotai intenzív', included in the experiment as the susceptible control, proved to be the third most susceptible. Similar, highly susceptible cultivars were SAR-33, SOM-274, OZSD-37 and ALB-22. Compared to the moderate resistant $(\mathrm{mR})$ 'Pedro' control cultivar, SZEN-10 and SOM-101 showed a major resistance and these differences were statistically significant $(\mathrm{p}<0.05)$.

The dendogram (Fig. 3), containing the annual diameter of the necrotic spots and the disease rate values, differentiated the cultivars belonging to certain susceptibility classes - from the susceptible group to less susceptible ones. The results from different years regarding the degree of susceptibility/resistance of cultivars showed a correspondence for the majority of cultivars; in the case of those cultivars, which showed a major difference between the annual results, it was accepted the classification from the dendogram.

Rovira et al. (2007) considered the artificial inoculation applied to be important because open field recordings of cultivar susceptibility are not sufficient.

The reaction of the studied cultivars to the $X a j$ bacteria was measured for the first time using in vitro experiment with an inoculation method; therefore, only the control cultivar data can be compared to previous results. Several studies provide information regarding the degree of susceptibility to bacterial blight of 'Hartley' and 'Pedro'. Özaktan et al. (2007, 2008) evaluated the susceptibility of several cultivars with artificial inoculation, and based on data from 2007, it was determined a low susceptibility for 'Pedro' (blight severity $=14.1 \%$ ) and a moderate susceptibility according to data from 2008 (blight severity=55\%). In the current experimental data, in 2011 'Pedro' showed a moderate resistance, while in 2012 it was determined moderate susceptible. Information about the susceptibility of 'Hartley' and 'Milotai 10' cultivars can be obtained from the results of Tsiantos et al. (2008). Based on the 2007 and 2008 Varietal Susceptibility Index (VSI) values and the susceptibility classes, 'Hartley' proved to be moderate susceptible (VSI $=25$; Class of Susceptibility=B), while 'Milotai 10 ' was found susceptible (VSI $=80$, Class of Susceptibility = D). Solar et al. (2008, 2009) also determined a moderate susceptibility in case of 'Hartley' cultivar. According to the current results 'Hartley' turned out to be susceptible in 2011, yet moderate susceptible in 2012.

Thiesz et al. (2007) considered the Transylvanian cultivars to have a low susceptibility against Xaj. According to the seven year results of Szani (2009), cultivars improved in Hungary showed a low or moderate infection rate. Based on the annual measurements it can be concluded that the majority of analysed cultivars were moderate susceptible $(\mathrm{mS})$ and susceptible (S). Among the cultivars improved in Hungary, 'Milotai kései', 'Alsószentiváni 118', M-10-25 and 'Milotai bőtermő' showed a low degree of susceptibility. Among the Transylvanian selections, SZEN-10 and SOM101 showed a notable reaction, since according to the annual results they were determined with moderate resistance (mR) and a moderate susceptibility $(\mathrm{mS})$.

\section{Conclusions}

The present research provided comprehensive results regarding the degree of susceptibility/resistance of the studied cultivars. Previous open field $X a j$ assessments based on the leaf quality proved that the cultivars have a good resistance to the disease. However, during the current experiment regarding artificial inoculation of immature fruits, it was 
proved that several cultivars have Xaj susceptibility. Therefore, the evaluation based on the leaf was found not reliable. Thus it may be concluded that the 'Pedro' transmitted the Xaj resistance into certain progeny. This could prove effective as a gene source in further improvements and for production in the environmental conditions of the Carpathian Basin. The results of these analyses show that, with adequate results regarding cultivar susceptibility, the losses caused by Xaj bacteria can be reduced.

\section{Acknowledgements}

This work was supported by the TAMOP 4.2.1./B09/1/KMR-2010-0005 project.

\section{References}

Aletà N, Ninot A (1993). Variedades de nogal. Fruticultura Profesional 54:93-100.

Bandi A, Tóth M, Hevesi M (2014). Comparison of Xanthomonas arboricola pv.juglandis isolates from walnut trees grown in Romania and Hungary. International Journal of Horticultural Science 20(12):65-69.

Belisario A (1997). Susceptibility and factors predisposing to Xanthomonas campestris pv. juglandis in walnut nurseries. Informatore Fitopatologica 47:60-63.

Belisario A, Palangio C, Zoina A (1997). Suscettibilita e fattori predisponenti a Xanthomonas campestrispv. juglandisin vivaio di noce comune. Informatore Fitopatologico 4:60-64.

Belisario A, Zoina A, Pezza L, Luongo L (1999). Susceptibility of species of Juglans to pathovars of Xanthomonas campestris. Eur J Forest Pathol 29:75-80.

Bertrand PF, Gottwald TR (1986). Evaluating fungicides for pecan disease control. In: Methods for evaluating pesticides for control of plant pathogens, Hickey KD (Ed). APS Press, St-Paul, Minnesota pp 179-181.

Charlot G, Radix P (1993). Bactériose du noyer. Composés phénoliques et résistance. Infos Ctif94:31-32.

Ferraris T (1927). Trattato di patologia e terapia vegetale. Vol. 2. U. Hoepli, Milano, $1032 \mathrm{p}$.

Germain E (1997). Genetic improvement of the Persian walnut (Juglans regia L.). In III International Walnut Congress 442 Acta Hort (ISHS) 442:21-31.

Klement Z (1963). Rapid detection of the pathogenicity of phytopathogenic pseudomonads. Nature 199:299-300.

Loreti S, Gallelli A, Belisario A, Wajnberg E, Corazza L (2001). Investigation of genomic variability of Xanthomonas arboricola pv. juglandis by AFLP analysis. EurJ Plant Pathol 107:583-591.

Martins MS (1997). Bacterial blight of walnut: A strategy for research. In III International Walnut Congress 442 Acta Hort (ISHS) 442:351-355.

Özaktan H, Erdal M, Akkopru A, Aslan E (2007). Evaluation of susceptibility of some walnut cultivars to Xanthomonas arboricola pv. juglandis by immature nut test. Available at: www.cost873.ch (accessed October 29, 2014).

Özaktan H, Erdal M, Akkopru A, Aslan E (2008). Evaluation of susceptibility of some walnut cultivars to Xanthomonas arboricola pv. juglandis by immature nut test. Available at: www.cost873.ch (accessed October 2, 2014).

Pierce NB (1901). Walnut bacteriosis. Botanical Gazette 31:272-273.

Rovira M, Moragrega C, Aletà N (2007). Susceptibility study to Xanthomonas arboricola pv.juglandis of immature fruits in two 'fullsib' walnut progenies. Available at: www.cost873.ch (accessed September 29, 2014).

Sharma LR, Sharma YP (1999). Diseases of temperate nut crops. In: Diseases of Horticultural Crops-Fruits, Verma LR, Sharma RC (Eds). Indus Publishing Company, New Delhi pp 209.

Solar A, Dreo T, Miculic-Potrovsej M, Lizocar A, Sustarsic M, Veberic R, Maticic L, Ravnicar M, Stampar F (2009). Phenolic compounds as potential markers for walnut blight resistance. Available at: www.cost873.ch (accessed October 5, 2014).

Solar A, Jakopic J, Mikulic-Petkovsek M, Veberic R, Dreo T, Zadravec P, Stampar F (2008). Validation of polyphenol contents as biochemical markers for walnut blight (Xanthomonas arboricola pv. juglandis) resistance. Available at: www.cost873.ch (accessed September 25, 2014).

Solar A, Jakopic J, Veberic R, Stampar F (2007). Phenolic compounds as a potential marker of walnut resistance against Xanthomonas arboricola pv. juglandis. Available at: www.cost873.ch (accessed November 29, 2014).

Soltani J, Aliabadi AA (2010). Genetic resistance to bacterial blight disease in Persian walnut. Eur J Plant Pathol 128:65-70.

Szani Z (2009). Biotic and abiotic stress factors influence on walnut varieties bred in Central Europe. Cereal Research Communications Supplement 37:329-332.

Szentiványi P (1990). Breeding early fruiting high producing walnut cultivars leafing after late spring frosts. Acta Hort 284:175-182.

Thiesz R, Bandi A, Tóth M, Balog A (2007). Epidemiological survey of Xanthomonas arboricola pv. juglandis and Gnomonia leptostyla on natural population of walnut (Juglans regia) in eastern Transylvania. International Journal of Horticultural Science 13(4):7-11.

Thiesz R, Bandi A, Toth M, Balog A (2009). Evaluation of an isolated Persian walnut (Juglans regia L.) population from Eastern Transylvania, Romania. Journal of Food, Agriculture and Environment 6(3-4):132-136.

Tsiantos J, Vagelas IK, Rumbos CI, Chatzaki A, Rouskas D, Gravanis FT (2008). Evaluation of resistance of cultivated walnut varieties and selections to Xanthomonas arboricola pv. juglandis in Greece. Available at: www.cost873.ch (accessed October 14, 2014).

Tulecke W, McGranahan G (1994). The walnut germplasm collection at the University of California, Davis. A description of the collections and a history of the breeding program of Eugene F. Serr and Harold I. Forde. Univ. Calif. Genet. Resour. Conserv Program, Davis, Report no 13:16-25.

Vauterin L, Hoste B, Kersters K, Swings J (1995). Reclassification of Xanthomonas. Int J Syst Bacteriol 45:472-489.

Woeste KE, McGranahan GH, Schroth NM (1992). Variation among Persian walnuts in response to inoculation with Xanthomonas campestris pv.juglandis.J Am Soc Hort Sci 117(3):527-531. 